Check for updates

Cite this: RSC Adv., 2018, 8, 18972

Received 1st April 2018

Accepted 10th May 2018

DOI: $10.1039 / \mathrm{c} 8 \mathrm{ra02804d}$

rsc.li/rsc-advances

\section{Cyclization of secondarily structured oligonucleotides to single-stranded rings by using Taq DNA ligase at high temperatures $\dagger$}

\author{
Yixiao Cui, (D) $\ddagger^{a}$ Xutiange Han, $\ddagger^{a}$ Ran An, (D) *ab Guangqing Zhou, ${ }^{a}$ \\ Makoto Komiyama ${ }^{\mathrm{ac}}$ and Xingguo Liang (D) *ab
}

Single-stranded DNA rings play important roles in nanoarchitectures, molecular machines, DNA detection, etc. Although T4 DNA ligase has been widely employed to cyclize single-stranded oligonucleotides into rings, the cyclization efficiency is very low when the oligonucleotides (l-DNAs) take complicated secondary structures at ambient temperatures. In the present study, this problem has been solved by using Thermus aquaticus DNA ligase (Taq DNA ligase) at higher temperatures (65 and $70{ }^{\circ} \mathrm{C}$ ) where the secondary structures are less stable or completely destroyed. This method is based on our new finding that this ligase successfully functions even when the splint strand is short and forms no stable duplex with I-DNA (at least in the absence of the enzyme). In order to increase the efficiency of cyclization, various operation factors (lengths and sequences of splint, as well as the size of the DNA ring) have been investigated. Based on these results, DNA rings have been successfully synthesized from secondarily structured oligonucleotides in high yields and high selectivity. The present methodology is applicable to the preparation of versatile DNA rings involving complicated secondary structures, which should show novel properties and greatly widen the scope of DNA-based nanotechnology.

\section{Introduction}

Recently, much attention has been focused on DNA-based nanoarchitectures which are applicable to nanomachines, drug delivery systems, etc. ${ }^{\mathbf{1 - 4}}$ Among the many nanostructures fabricated from DNA, single-stranded DNA rings are characterized by dynamic and mobile features which cannot be otherwise fulfilled, and they are one of the most important and promising parts in nanoarchitectonics. ${ }^{5-7}$ For example, catenanes, in which two or more DNA rings are mechanically interlocked, have been elegantly employed in molecular switches, molecular motors, and switchable catalysts. ${ }^{7-10}$ Versatile applications of DNA rings to molecular biology, medicine, and biotechnology have also been reported. ${ }^{11-19}$ In most cases, DNA rings were prepared by cyclizing linear singlestranded DNA (1-DNA) with the use of T4 DNA ligase at room temperature. ${ }^{20-23}$ The cyclization has been greatly facilitated by adding an oligonucleotide (splint strand), which is

${ }^{a}$ College of Food Science and Engineering, Ocean University of China, Qingdao 266003, China.E-mail: ar@ouc.edu.cn; liangxg@ouc.edu.cn

${ }^{b}$ Laboratory for Marine Drugs and Bioproducts, Qingdao National Laboratory for Marine Science and Technology, Qingdao 266003, China

${ }^{c}$ National Institute for Materials Science (NIMS), Namiki, Tsukuba 305-0044, Japan $\dagger$ Electronic supplementary information (ESI) available. See DOI: 10.1039/c8ra02804d

$\ddagger$ These authors contributed equally to this work as first authors. complementary with the $3^{\prime}$ - and $5^{\prime}$-terminal portions of l-DNA (see pathway 1 in Scheme 1). There are two critical problems which must be solved for more efficient production of DNA rings and also for their more sophisticated applications. The

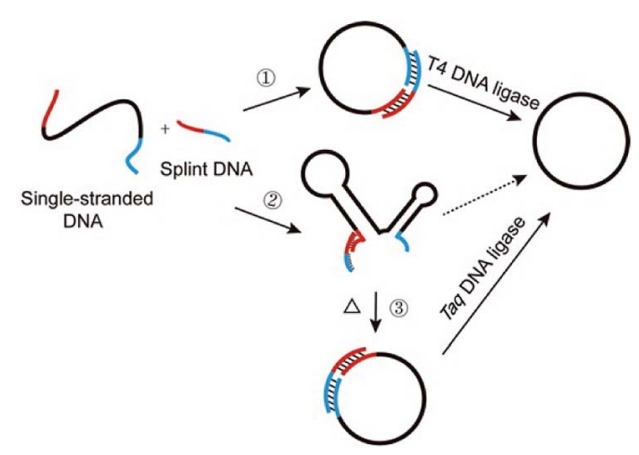

Scheme 1 Schematic view of cyclization of single-stranded linear DNA (l-DNA) by DNA ligase. In pathway 1, l-DNA takes no secondary structure at $25^{\circ} \mathrm{C}$ and is successfully cyclized by T4 DNA ligase with the assistance of splint DNA. In pathway 2, however, l-DNA is folded to a complicated secondary structure at $25^{\circ} \mathrm{C}$, and thus is hardly cyclized by T4 DNA ligase at $25^{\circ} \mathrm{C}$, even in the presence of splint DNA. In pathway 3, this problem is solved by using Taq DNA ligase and achieving the reactions at higher temperatures where the secondary structures are unstable. The ring structure of the final product is confirmed in terms of the resistance against the digestion by Exonuclease I. 
first problem is the formation of enormous amounts of polymeric byproducts in their production processes, which has been well recognized for a long time. The targeted intramolecular cyclization is inevitably accompanied by intermolecular polymerization of l-DNA, and thus the yield and selectivity for desired DNA rings are limited. The most popular solution is high dilution method, in which the intermolecular reactions are suppressed by decreasing the concentration of l-DNA. ${ }^{\mathbf{2 4 , 2 5}}$ By this strategy, however, the amounts of DNA rings obtainable are intrinsically small. Recently, this problem has been solved, at least for T4 DNA ligase-mediated cyclization, by employing abnormally diluted buffers as well as a step-by-step operation, since intermolecular polymerization was minimized under these conditions. ${ }^{26}$

Another critical problem is the formation of secondary structures of DNAs in solutions at ligation temperatures, which hampers the formation of DNA rings and should also govern the scope of applications of DNA rings. In spite of its essential roles, this factor has never been attracting much attention to date. An eminent solution to this problem is the primary concern of this paper. In contrast with rigid helix-structure of double-stranded DNA, single-stranded DNA is flexible and easily folded to complicated secondary structures through intramolecular basepairing and/or stacking interactions. ${ }^{27}$ In fact, many of naturally occurring single-stranded DNAs have been reported to form secondary structures, which strongly affect their biological functions. ${ }^{28}$ Various functional DNAs artificially developed (e.g. aptamers, G quadruplex and DNAzymes) are also complicatedly folded. ${ }^{4}$ Besides, these secondary structures were often designed on DNA rings to construct molecular machines. ${ }^{29}$ In these structures, the two ends of oligonucleotide are often oriented unfavorably to be intramolecularly cyclized into rings. The secondary structures should also suppress the binding of splint strand to l-DNA at lower temperatures, since additional energy is required to deform the structures. Accordingly, the versatility of l-DNAs available (thus of DNA rings) is significantly limited in conventional methods (pathway 2 in Scheme 1). Furthermore, the secondary structures in DNA rings, if any, should strongly affect the dynamic, biological, and other properties of nanostructures, and thus unique rings of unprecedented features and potentialities should be obtainable. Accordingly, enzymatic cyclization of secondarily structured oligonucleotide is an urgent topic in the relevant science.

In this study, l-DNAs having complicated secondary structures are efficiently and selectively cyclized to DNA rings at high temperatures where these structures are unstable (pathway 3 in
Scheme 1). In place of heat-sensitive T4 DNA ligase, thermostable Taq DNA ligase from aquatic thermophilic bacteria ${ }^{30-32}$ is successfully used on the basis of our unexpected finding of new aspect of this enzyme (see the Results section). Various reaction conditions (the length of splint strand, GC content in the splint, size of DNA ring, and the concentration of Taq DNA ligase buffer) are optimized to suppress the formation of polymeric byproducts. As the results, single-stranded DNA rings of various sizes are synthesized in high yield and selectivity, even when the corresponding l-DNA is folded to complicated secondary structure in solutions at room temperature. Without complicated purification procedures, DNA rings of high purity $(>90 \%)$ have been easily obtained in a preparative scale.

\section{Materials and methods}

\section{Materials}

Single-stranded oligonucleotides (in Tables 1 and S1†) were purchased from GENEWIZ (Suzhou, China). The sequence of 1DNA $_{59}$ was a part of l-DNA ${ }_{74}$, which was from phage M13, and their secondary structures were determined by Mfold calculation. ${ }^{33}$ Prior to the cyclization experiments, a phosphate residue was enzymatically introduced to the $5^{\prime}$-position of these linear DNAs (l-DNAs) by using T4 polynucleotide kinase (Thermo Scientific, Pittsburgh, PA. USA). The products were purified by PAGE. Thermus aquaticus (Taq) DNA ligase was obtained from NEW ENGLAND BioLabs (Beijing, China), together with $10 \times$ Taq DNA ligase buffer. T4 DNA ligase was purchased from Thermo Scientific (Pittsburgh, PA. USA), together with $10 \times \mathrm{T} 4$ DNA ligase buffer. Exonuclease I was from Thermo Scientific (Pittsburgh, PA. USA). All other chemicals were from SigmaAldrich (St. Louis, MO. USA).

Cyclization of single-stranded linear DNA (1-DNA) by Taq DNA ligase. Unless noted otherwise, the reactions were carried out in $1 \times$ Taq DNA ligase buffer $\left([\mathrm{KAc}]=10 \mathrm{mM},\left[\mathrm{Mg}(\mathrm{Ac})_{2}\right]=\right.$ $10 \mathrm{mM},[\mathrm{NAD}]=1 \mathrm{mM}$, [Tris- $\mathrm{HCl}]=20 \mathrm{mM}$, and $0.1 \%$ Triton $\mathrm{X}-$ $100)$. The reaction mixture $(20 \mu \mathrm{L})$ containing l-DNA $(5 \mu \mathrm{M})$ and splint strand $(10 \mu \mathrm{M})$ was first heated at $90{ }^{\circ} \mathrm{C}$ for $3 \mathrm{~min}$, and cooled with ice. Then, Taq DNA ligase (40 U) was added, and the mixture was incubated at $65{ }^{\circ} \mathrm{C}$ or $70{ }^{\circ} \mathrm{C}$ for $12 \mathrm{~h}$. The reaction was terminated by adding the dye solution (50\% glycerin, $50 \mathrm{mM}$ EDTA and bromophenol blue).

Cyclization of 1-DNA by T4 DNA ligase. The cyclization mixture $(20 \mu \mathrm{L})$ containing l-DNA $(5 \mu \mathrm{M})$ and splint $(10 \mu \mathrm{M})$ in $1 \times \mathrm{T} 4$ DNA ligase buffer $\left([\mathrm{ATP}]=500 \mu \mathrm{M},\left[\mathrm{MgCl}_{2}\right]=10 \mathrm{mM}\right.$, $[\mathrm{DTT}]=10 \mathrm{mM}$, and $[$ Tris $-\mathrm{HCl}]=40 \mathrm{mM}$ ) was heated at $90{ }^{\circ} \mathrm{C}$

Table 1 The sequences of typical l-DNAs and splints used in this study

\begin{tabular}{|c|c|c|}
\hline Name & Sequences $\left(5^{\prime} \rightarrow 3^{\prime}\right)$ & Length (nt) \\
\hline l-DNA 59 & GACGTTGGAGTCCACGTTCTTTAATAGTGGACTCTTGTTCCAAACTGGAACAACACTCA & 59 \\
\hline splint $_{59}{ }^{(6+6)}$ & AACGTCTGAGTG & 12 \\
\hline l-DNA 74 & CCTTTGACGTTGGAGTCCACGTTCTTTAATAGTGGACTCTTGTTCCAAACTGGAACAACACTCAACCCTATCTC & 74 \\
\hline splint $_{74}(6+6)$ & CAAAGGGAGATA & 12 \\
\hline splint $_{74}(13+12)$ & CCAACGTCAAAGGGAGATAGGGTTG & 25 \\
\hline
\end{tabular}


for $3 \mathrm{~min}$ and cooled with ice. Then, the reaction was initiated by adding T4 DNA ligase (10 U), achieved at $25{ }^{\circ} \mathrm{C}$ for $12 \mathrm{~h}$, and terminated by heating the mixture at $65{ }^{\circ} \mathrm{C}$ for $10 \mathrm{~min}$.

Cyclization in diluted Taq DNA ligase buffer. The $10 \times$ Taq DNA ligase buffer from the commercial source was simply diluted by water, and used for the reactions. Otherwise, all the procedures were exactly the same as those described above.

Evaluation of selectivity and yield for the formation of DNA rings. The reaction products were analyzed on $10 \%$ denaturing polyacrylamide gel (dPAGE), and stained with the dye solution presented above. The intensity of fluorescence emission from each band was quantified by Image Lab software. The selectivity and the yield for the formation of DNA rings were calculated by eqn (1) and (2):

$$
\begin{gathered}
\text { Selectivity }(\%)=\frac{C}{B+C} \times 100 \\
\text { Yield }(\mathrm{mol} \%)=\frac{C}{B+C+R} \times 100,
\end{gathered}
$$

where $C, B$, and $R$ were the band intensities of circular singlestranded DNA ring, polymeric byproducts, and remained single-stranded linear DNA (l-DNA), respectively.

\section{Results}

\section{Successful cyclization of l-DNA by Taq DNA ligase at high temperatures where the splint hardly forms stable duplex with 1-DNA}

The secondarily structured DNAs we used here have apparent $T_{\mathrm{m}}$ of around $65{ }^{\circ} \mathrm{C}$ (the values of $1-\mathrm{DNA}_{59}$ and $1-\mathrm{DNA}_{74}$, measured by high resolution melting method, ${ }^{34,35}$ are 65.1 and $66.4{ }^{\circ} \mathrm{C}$ respectively; Fig. S1 $\dagger$ ). Thus, the enzymatic cyclization of these DNAs into rings must be achieved at $65{ }^{\circ} \mathrm{C}$ or higher where the secondary structures are largely deformed. However, this requirement is not easily compatible with the reaction conditions conventionally used for Taq DNA ligase, especially for a relatively short splint. As far as we know, most of the previous ligations of nicked DNA were carried out under the conditions that the duplexes in both sides of nick site are sufficiently long and stably formed at the reaction temperature. For example, a splint of $40 \mathrm{nt}$ or longer was often employed for the ligation at $60{ }^{\circ} \mathrm{C}$ or lower. ${ }^{36-38}$ However, such long splints cannot be used for selective DNA ring production, since they cover a large portion of l-DNAs and the cyclic intermediates are hard to be formed due to higher rigidity, especially for a short l-DNA. Very recently, however, we have unexpectedly found that much shorter splint is sufficiently effective for this enzymatic ligation at $65{ }^{\circ} \mathrm{C}$ (Fig. S2 $\dagger$ ). The ligation satisfactorily proceeded even with the use of an $18 \mathrm{nt}$ splint, which formed $9 \mathrm{bp}$ duplexes on both sides of the nick. Both duplexes have low $T_{\mathrm{m}}$ values $\left(50{ }^{\circ} \mathrm{C}\right.$ or lower), and are never stably formed at $65{ }^{\circ} \mathrm{C}$, at least in the absence of the enzyme. Apparently, temporarily formed duplexes are responsible for this enzymatic ligation. The binding between l-DNA and splint could be promoted by the assistance of the enzyme. These remarkable findings have paved the way to the production of single-stranded DNA rings with the use of Taq DNA ligase and short splint (e.g. $25 \mathrm{nt}$ ) at $65{ }^{\circ} \mathrm{C}$, where the secondary structures of l-DNAs are unstable. Certainly, similar cyclization can be also successful for l-DNAs without obvious secondary structures (date not shown).

\section{Superiority of Taq DNA ligase over T4 DNA ligase to cyclize secondarily structured DNA into DNA ring}

In Fig. 1, two linear DNAs (l-DNAs) were treated with Taq DNA ligase and T4 DNA ligase in the presence of two splints of different lengths (the sequences are shown in Table 1). The reactions were achieved in $1 \times$ Taq DNA ligase buffer and $1 \times \mathrm{T} 4$ DNA ligase buffer from commercial sources. According to Mfold calculation $\left(\left[\mathrm{Mg}^{2+}\right]=10 \mathrm{mM}\right.$ at $\left.25^{\circ} \mathrm{C}\right)$, both of l-DNA 59 and $\mathrm{l}-$ $\mathrm{DNA}_{74}$ (59 and $74 \mathrm{nt}$ ) take complicated secondary structures at ambient temperatures, which are unfavorable for the cyclization (see A and B in Fig. 1). Accordingly, l-DNA 59 was hardly cyclized by T4 DNA ligase at $25{ }^{\circ} \mathrm{C}$, when $12 \mathrm{nt}$ oligonucleotide (splint $_{59}{ }^{(6+6)}$ ) was used as helper strand (lane 2). Only intermo-

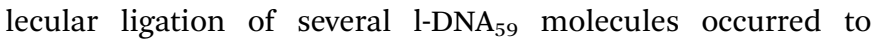
produce the polymeric byproducts (the bands of low mobility in the top of gel). In order to deform the secondary structure involving two loops and allow the cyclization, a longer splint is necessary. Thus, $25 \mathrm{nt}$ splint (splint $_{59}{ }^{(13+12)}$ ), which is complementary with $13 \mathrm{nt}$ in the $5^{\prime}$-end of l-DNA 59 and $12 \mathrm{nt}$ in the $3^{\prime}$ end, was used for cyclization by T4 DNA ligase in lane 3. Some amount of DNA ring (c-DNA 59 ) was formed (the band at the bottom of the gel). However, the polymers were still the major products, and the selectivity for the DNA ring was only $38 \%$.

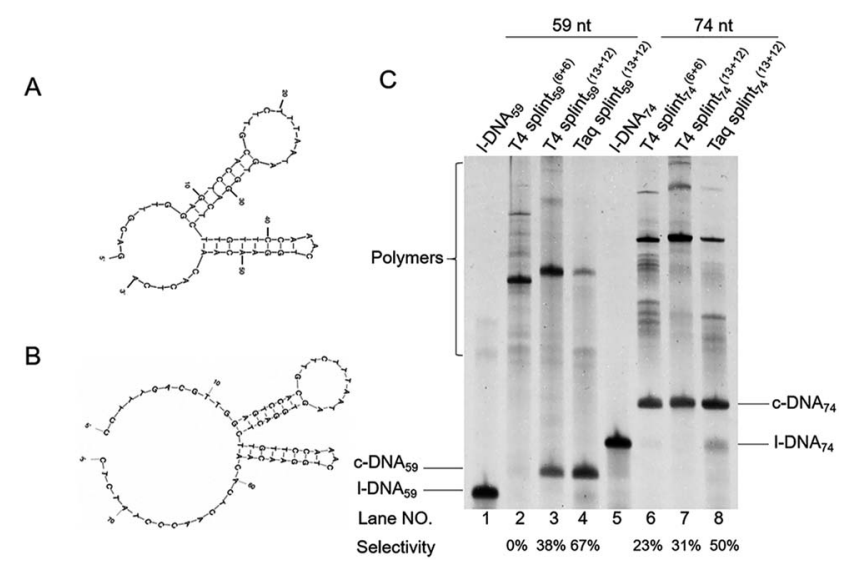

Fig. 1 Cyclization of I-DNAs by Taq DNA ligase and T4 DNA ligase. Both $1-D^{-A_{59}}$ (A) and $1-\mathrm{DNA}_{74}$ (B) take secondary structures, as determined by Mfold calculation $\left(\left[\mathrm{Mg}^{2+}\right]=10 \mathrm{mM}\right.$ at $\left.25^{\circ} \mathrm{C}\right)$. In $(\mathrm{C})$, the cyclization was carried out under the following conditions: [l-DNA $]_{0}=$ $5 \mu \mathrm{M}$ and [12 or $25 \mathrm{nt}$ splint] $=10 \mu \mathrm{M}$. Lane 1, l-DNA 59 only; lane 2, DNA $_{59}$ with splint ${ }_{59}{ }^{(6+6)}$ at $25^{\circ} \mathrm{C}$ by T4 DNA ligase; lane 3, l-DNA ${ }_{59}$ with splint $_{59}{ }^{(13+12)}$ at $25{ }^{\circ} \mathrm{C}$ by T4 DNA ligase; lane 4, l-DNA ${ }_{59}$ with splint $_{59}{ }^{(13+12)}$ at $65^{\circ} \mathrm{C}$ by Taq DNA ligase; lane 5, l-DNA 74 only; lane 6, lDNA $_{74}$ with splint ${ }_{74}{ }^{(6+6)}$ at $25^{\circ} \mathrm{C}$ by T4 DNA ligase; lane 7, I-DNA 74 with splint $_{74}{ }^{(13+12)}$ at $25{ }^{\circ} \mathrm{C}$ by T4 DNA ligase; lane 8, l-DNA $_{74}$ with splint ${ }_{74}{ }^{(13+12)}$ at $65^{\circ} \mathrm{C}$ by Taq DNA ligase. Prior to the reactions, I-DNAs were phosphorylated at the $5^{\prime}$-position by using T4 polynucleotide kinase. The sequences of I-DNAs and splints are listed in Table 1 and detailed reaction conditions are shown in Experimental section. The $T_{m}$ of $\mathrm{l}-\mathrm{DNA}_{59}$ and $\mathrm{l}-\mathrm{DNA}_{74}$ was $65.1^{\circ} \mathrm{C}$ and $66.4^{\circ} \mathrm{C}$ (Fig. S1 $\dagger$ ). 
In order to destroy the secondary structure of l-DNA $\mathrm{DA}_{59}$ and promote its intramolecular cyclization, the reaction was carried out at $65{ }^{\circ} \mathrm{C}$ by $\mathrm{Taq}$ DNA ligase (lane 4). It is worth mentioning that the apparent $T_{\mathrm{m}}$ of $1-\mathrm{DNA}_{59}$ is $65.1{ }^{\circ} \mathrm{C}$ (the corresponding value of $1-\mathrm{DNA}_{74}$ is $66.4{ }^{\circ} \mathrm{C}$; Fig. S1 $\dagger$ ). Exactly as designed, the formation of polymeric by-products were greatly suppressed, and the DNA ring was now obtained as the dominant product (67\% selectivity). This method was also applicable to the cyclization of l-DNA ${ }_{74}$, a longer oligonucleotide taking similar structure to l-DNA 59 (see Fig. 1B). By using Taq DNA ligase and $25 \mathrm{nt}$ splint (splint ${ }_{74}{ }^{(13+12)}$ ) at $65^{\circ} \mathrm{C}$, the DNA ring was prepared in $50 \%$ selectivity. This selectivity is much higher than the corresponding value (31\%) for the cyclization using T4 DNA ligase at $25{ }^{\circ} \mathrm{C}$ (compare lane 8 with lane 7 ). The ring structures of the products obtained by the present method have been confirmed in terms of complete resistance against Exonuclease I (Fig. S3 $\dagger$ ). It is concluded that thermostable Taq DNA ligase is a highly powerful and advantageous tool, compared with conventionally employed T4 DNA ligase, to prepare DNA rings from secondarily structured oligonucleotides. Note that a relatively higher DNA concentration ( $5 \mu \mathrm{M}$ l-DNA) was used here. This advantage of Taq DNA ligase can be further amplified in diluted Taq DNA ligase buffers, and the selectivity for the formation of DNA rings is further increased up to almost $100 \%$ (vide infra).

\section{Optimization of reaction conditions for efficient formation of DNA ring by Taq DNA ligase}

Length of splint strand. The reaction conditions for formation of DNA ring from l-DNA ${ }_{74}$ were optimized. At $65{ }^{\circ} \mathrm{C}$ (Fig. 2A) and $70{ }^{\circ} \mathrm{C}$ (Fig. 2B), the length of splint strand was systematically changed, and l-DNA ${ }_{74}$ was cyclized by Taq DNA ligase. The

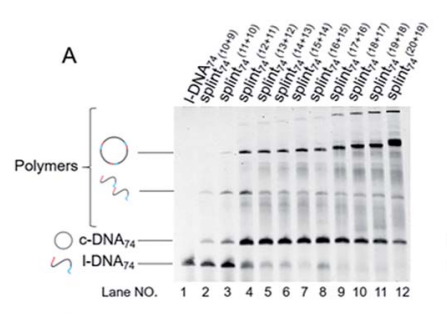

C

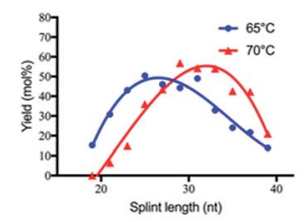

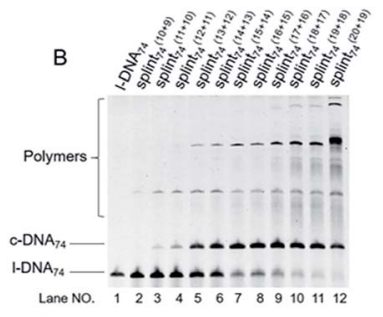

D

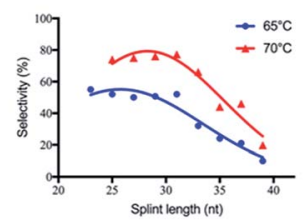

Fig. 2 Effects of the length of splint on the cyclization of l-DNA 74 by Taq DNA ligase at (A) $65^{\circ} \mathrm{C}$ and (B) $70^{\circ} \mathrm{C}$. The reaction conditions: [l$\left.\mathrm{DNA}_{74}\right]_{0}=5 \mu \mathrm{M}$; [splint] $=10 \mu \mathrm{M} ; 40 \cup$ Taq DNA ligase (in $20 \mu \mathrm{L}$ ). In (C) and (D), the yields and the selectivity at $65^{\circ} \mathrm{C}$ (circles) and $70{ }^{\circ} \mathrm{C}$ (triangles) are plotted as a function of splint length. The results in lanes 2 and 3 in (A) and lanes 2-4 in (B) were not incorporated to the plots in (D), since the band intensities of the products were too small to determine their ratios precisely. The sequences of splints are listed in Table S1.† dependencies of the yield of c-DNA ${ }_{74}$ and the selectivity for its formation on the splint length are presented in (C) and (D), respectively. At both $65{ }^{\circ} \mathrm{C}$ (circles) and $70{ }^{\circ} \mathrm{C}$ (triangles), the plots of yield $v s$. the splint length are bell-shaped, and the maxima are at around $25 \mathrm{nt}$ at $65^{\circ} \mathrm{C}$ and $29 \mathrm{nt}$ at $70^{\circ} \mathrm{C}$ (Fig. 2C). The maximum yield was 50-60 mol\%. On the other hand, at both temperatures, the selectivity remained rather constant up to the splint length $31 \mathrm{nt}$, indicating that the ratio of the reaction rate of intramolecular cyclization to the rate of intermolecular polymerization is almost constant here. With still longer splints, the selectivity gradually decreased with increasing splint length, corresponding to more dominant contribution of intermolecular polymerization. It should be noted again that efficient ligation was obtained at a temperature $10-15{ }^{\circ} \mathrm{C}$ higher than the $T_{\mathrm{m}}$ of the duplex of l-DNA/splint.

GC contents in the splint strand. In Fig. 3, l-DNAs (74 nt) are cyclized by Taq DNA ligase at $65{ }^{\circ} \mathrm{C}$, using splint strands which form different number of G-C pairs with the l-DNAs. In lanes 2 , $5,8,11,14$, and 17 , the lengths of splints are $18 \mathrm{nt}$, and the numbers of G-C pairs between the l-DNA and the splint are 0,6 , $10,11,14$, and 18, respectively. In all these splints, $9 \mathrm{nt}$ sequences in the $3^{\prime}$ - and $5^{\prime}$-sides, respectively, are complementary with the $3^{\prime}$ - and $5^{\prime}$-sides of l-DNA (see Table S1 $\dagger$ ). When the number of G-C pairs is smaller than 10 (18 base pairs in total), cyclic DNA rings are never produced (lanes 2, 5, and 8). For the preparation of ring products, the number of G-C pairs must be 11 or larger (lanes 11, 14, and 17). In order to place the two ends of l-DNA in a close proximity, the duplexes must have a reasonable $T_{\mathrm{m}}\left(\right.$ e.g. $>48{ }^{\circ} \mathrm{C}$, date not shown), although they do not have to be completely stable at the reaction temperature $\left(65{ }^{\circ} \mathrm{C}\right)$ (vide ante).

In the lanes adjacent to the lanes described above, the splints are $1 \mathrm{nt}$ shorter (in the $3^{\prime}$-side) or $1 \mathrm{nt}$ longer (in the $5^{\prime}$ side) than the parent splints.

These truncated and grafted splints $(9+8$ and $10+9$, respectively) provided virtually the same results with respect to GC contents as the parent $18 \mathrm{nt}$ splint. Necessity of sufficient number of G-C pairs for the cyclization has been further confirmed. The absence of ring products in lanes 10 and 13 (with $9+8$ splints) indicates that the splint of $18 \mathrm{nt}(9+9)$ or

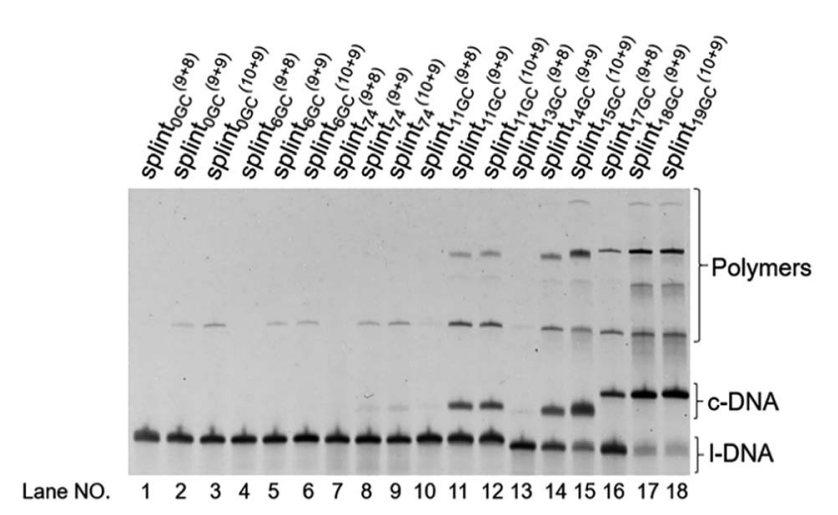

Fig. 3 Cyclization of l-DNA (74 nt) by Taq DNA ligase using the splints of various GC contents. Reaction conditions: [l-DNA $]_{0}=5 \mu \mathrm{M}$, [splint] $=10 \mu \mathrm{M}$, and $40 \mathrm{U}$ Taq DNA ligase (in $20 \mu \mathrm{L}$ ) at $65^{\circ} \mathrm{C}$ for $12 \mathrm{~h}$. The sequences of all the I-DNAs and the splints are shown in Table S1. $\dagger$ 
longer is desirable for efficient catalysis by Taq DNA ligase under the conditions employed here, although some circular DNA was obtained when $17 \mathrm{nt}$ splint with $100 \%$ GC content was used (lane 16). Consistently, no products of intermolecular polymerization are observed in lanes 10 and 13 .

Size of DNA ring. In Fig. 4, l-DNAs of different size were cyclized by Taq DNA ligase with the use of $29 \mathrm{nt}$ splint. All of these DNAs are folded to secondary structures (see Fig. S4†). As shown in lane 1, l-DNA of $64 \mathrm{nt}$ was successfully cyclized to cDNA $_{64}$ (the selectivity was 76\%). This result fairly agrees with the efficient cyclization of 1-DNA $\mathrm{DN}_{59}$ and 1-DNA ${ }_{74}$ in Fig. 1. For 1DNA $_{54}$ and l-DNA 44 , however, Taq DNA ligase was never eminent for the cyclization. It is concluded that the present method using Taq DNA ligase is applicable to the preparation of DNA rings of $60 \mathrm{nt}$ or larger, and T4 DNA ligase may be the better one for shorter DNA rings.

Concentration of Taq DNA ligase buffer. It was previously shown that, in the cyclization of oligonucleotides (having no secondary structures) by T4 DNA ligase, the target DNA rings can be synthesized in high yield and selectivity simply by decreasing the concentration of T4 DNA ligase buffer. ${ }^{26}$ In these diluted buffers, the formation of polymeric byproduct is greatly suppressed. Accordingly, Taq DNA ligase buffer was diluted and used for the present cyclization reactions (Fig. 5A). The initial concentration of $1-\mathrm{DNA}_{74}$ was $5 \mu \mathrm{M}$. With the decrease in the buffer concentration, the amounts of polymeric byproducts gradually decreased, and the selectivity for the DNA ring (c$\mathrm{DNA}_{74}$ ) monotonously increased (lanes $1-4$ for $65{ }^{\circ} \mathrm{C}$ and lanes 5-8 for $70{ }^{\circ} \mathrm{C}$ ). In $0.1 \times$ Taq DNA ligase buffer, for example, the selectivity of c-DNA 74 was almost $100 \%$ at $70{ }^{\circ} \mathrm{C}$.

Protocol for preparative synthesis of DNA rings from structured oligonucleotides using Taq DNA ligase. Even when the concentrations of l-DNA were still higher, DNA rings were also selectively formed in $0.1 \times$ Taq DNA ligase buffer at $70{ }^{\circ} \mathrm{C}$. When [l-DNA $\left.{ }_{74}\right]_{0}$ was $10 \mu \mathrm{M}$ (lane 4 in Fig. $5 \mathrm{~B}$ ), the selectivity for the cyclization to c-DNA ${ }_{74}$ was as high as $91 \%$ and its yield was $58 \%$

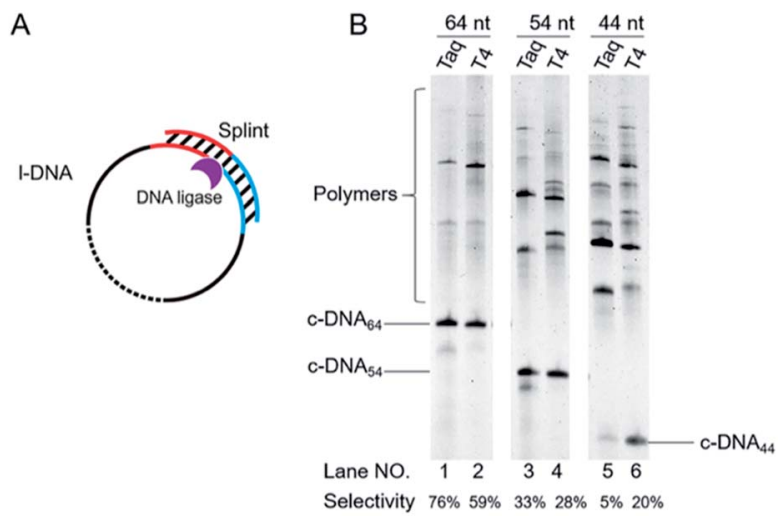

Fig. 4 Schematic of view of cyclization of l-DNA of different lengths by Taq DNA ligase (A). The reaction conditions in (B): [l-DNA 64 , l$\mathrm{DNA}_{54}$, or $\left[-\mathrm{DNA}_{44}\right]_{0}=5 \mu \mathrm{M}$, splint $\left._{74}{ }^{(15+14)}\right]=10 \mu \mathrm{M}$, and $40 \cup$ Taq DNA ligase (in $20 \mu \mathrm{L}$ ) at $65^{\circ} \mathrm{C}$ for $12 \mathrm{~h}$. For the purpose of comparison, ssplint $\left._{74}{ }^{(6+6)}\right]=10 \mu \mathrm{M}$ and the results with T4 DNA ligase at $25^{\circ} \mathrm{C}$ are also presented. The sequences of l-DNAs and splints are listed in Table S1.†

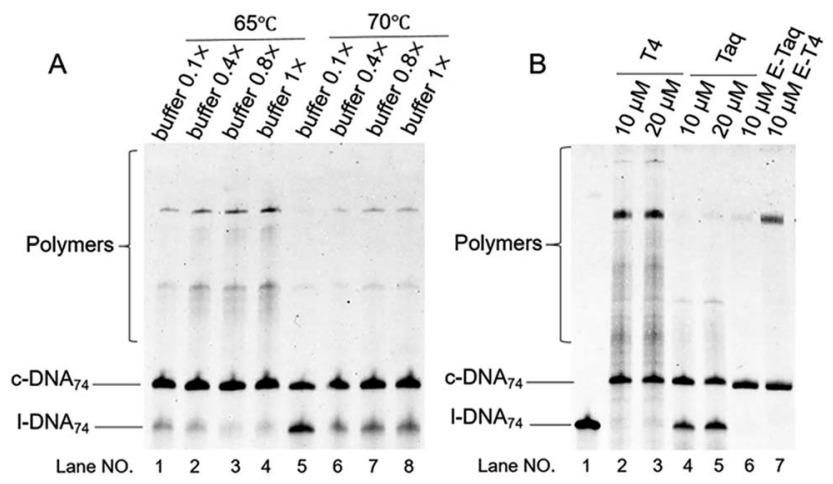

Fig. 5 Diluted buffer improves the selectivity. (A) Effect of the concentration of Taq DNA ligase buffer on the cyclization of $L_{-D N A}$ by Taq DNA ligase. Diluted buffers were employed under the conditions: $\left[\text { l-DNA }{ }_{74}\right]_{0}=5 \mu \mathrm{M}$, splint $\left._{74}{ }^{(15+14)}\right]=10 \mu \mathrm{M}$, and $40 \cup$ Taq DNA ligase (in $20 \mu \mathrm{L}$ ) for $12 \mathrm{~h}$. (B) Effect of the initial concentration of l$\mathrm{DNA}_{74}$ in $0.1 \times$ Taq DNA ligase buffer at $70{ }^{\circ} \mathrm{C}$. [l-DNA $\left.{ }_{74}\right]_{0} /$ [splint $\left.74{ }^{(15+14)}\right]=1 / 2$. For the purpose of comparison, the results with T4 DNA ligase in 0.1× T4 DNA ligase buffer are also shown. In lanes 6 and 7 in (B), the products in lanes 2 and 4, respectively, were treated with Exonuclease I to digest non-cyclic DNAs.

(see Table 2). Accordingly, the final reaction mixture contained only c-DNA ${ }_{74}$ and $1-\mathrm{DNA}_{74}$ (the remaining starting materials), together with marginal amounts of polymeric byproducts. Thus, simply by treating the product with Exonuclease I and digesting non-cyclic DNAs, the DNA ring as the desired product was obtained in $94 \%$ purity (see Table 2 ). No specific byproducts were perceived in the gel (lane 6 in Fig. 5B). Thus, even without complicated purification procedure such as column chromatography, the DNA ring can be successfully obtained in a high purity enough to be directly usable for many applications. The preparation of DNA ring was also satisfactory at $\left[1-\mathrm{DNA}_{74}\right]_{0}=20$ $\mu \mathrm{M}$ (lane 5 in Fig. 5B)

With the use of T4 DNA ligase in $0.1 \times$ T4 DNA ligase buffer at $25{ }^{\circ} \mathrm{C}$, however, notable amounts of polymeric byproducts were formed when $\left[1-\mathrm{DNA}_{74}\right]_{0}=10 \mu \mathrm{M}$ (lane 2 in Fig. 5B). The selectivity was $40 \%$. At $\left[\mathrm{l}-\mathrm{DNA}_{74}\right]_{0}=20 \mu \mathrm{M}$, the selectivity was only $29 \%$ (lane 3 in Fig. $5 \mathrm{~B}$ and Table 2). Apparently, this method is not very useful to cyclize secondarily structured 1DNA, although it is powerful for the cyclization of l-DNA without secondary structures. ${ }^{26}$ Furthermore, it is noteworthy that the major byproduct was a cyclic oligomer, which is resistant against Exonuclease I (the band near the top of gel). Thus, even after the digestion of the product in lane 2 by Exonuclease I, the desired "monomeric" ring $\left(\mathrm{c}-\mathrm{DNA}_{74}\right)$ was contaminated with notable amount of this cyclic oligomer (lane 7 in Fig. 5B), and its purity was only $61 \%$ (see Table 2). Superiority of Taq DNA ligase for the production of DNA rings is completely evidenced.

\section{Discussion}

In the present study, oligonucleotides having complicated secondary structure in solutions (l-DNA) are for the first time intramolecularly cyclized in high yield and selectivity to single- 
Table 2 Selective preparation of DNA ring $\left(c-D N A_{74}\right)$ from $1-D N A_{74}$

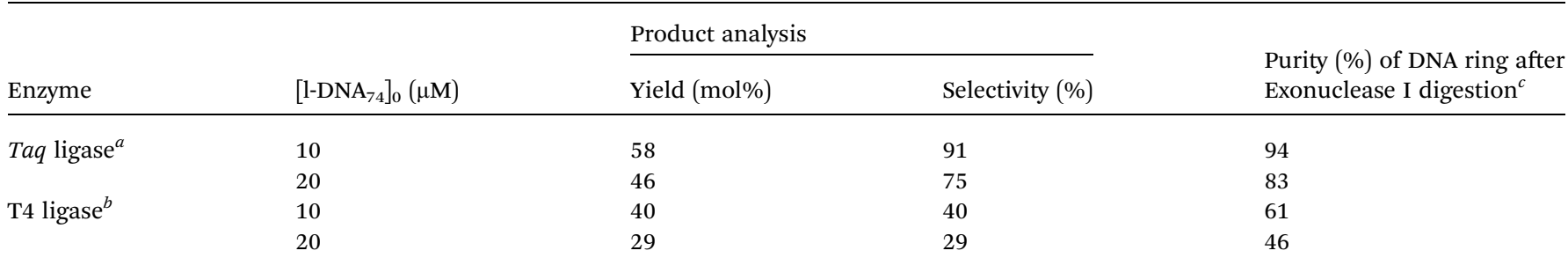

${ }^{a}\left[1-\mathrm{DNA}_{74}\right]_{0} /\left[\operatorname{splint}_{74}{ }^{(15+14)}\right]=1 / 2, \mathrm{Taq}$ DNA ligase $=40 \mathrm{U}($ in $20 \mu \mathrm{L}), 0.1 \times \operatorname{Taq}$ DNA ligase buffer, $70{ }^{\circ} \mathrm{C}, 12 \mathrm{~h}^{b}{ }^{b}\left[1-\mathrm{DNA} \mathrm{DA}_{74} /\left[\mathrm{splint}_{74}{ }^{(15+14)}\right]=1 / 2, \mathrm{~T}_{4}\right.$ DNA ligase $=10 \mathrm{U}($ in $20 \mu \mathrm{L}), 0.1 \times \mathrm{T} 4$ DNA ligase buffer, $25^{\circ} \mathrm{C}, 12 \mathrm{~h}^{c}{ }^{c}$ The purity of the DNA ring obtained after simple treatment of the enzymatic products with Exonuclease I (without any separation procedures).

stranded DNA rings. By using thermostable Taq DNA ligase at $65-70{ }^{\circ} \mathrm{C}$, the problems of conventional method using T4 DNA ligase (dominant production of polymeric byproducts and the resultant low selectivity for the desired DNA rings) have been solved. The essential points of the present preparation of DNA rings are (i) to achieve the cyclization at high temperatures in which the secondary structures are unstable, (ii) to use splint strand of appropriate length and GC content which binds with lDNA with reasonable stability at high temperatures, and (iii) to decrease the concentration of Taq DNA ligase buffer to minimize the production of polymeric byproducts.

The NAD ${ }^{+}$-dependent Taq DNA ligase, like ATP-dependent T4 DNA ligase, also involves the lysine-mediated adenylation of the $5^{\prime}$-phosphate at the end of one DNA strand. ${ }^{30}$ In the following step, the resultant pyrophosphate is attacked by the $3^{\prime}-\mathrm{OH}$ of an adjacent DNA strand, joining two strands by a stable phosphodiester linkage. In the mixtures for the present cyclization, multiple equilibria hold as schematically depicted in Scheme 2 (only the minimum set of species, some of which are only temporarily formed, is shown here). The oligonucleotide is folded to complicated secondary structure I in solutions, but deformed to less structured form II at higher temperature. When a splint strand is added to the solution, several composite

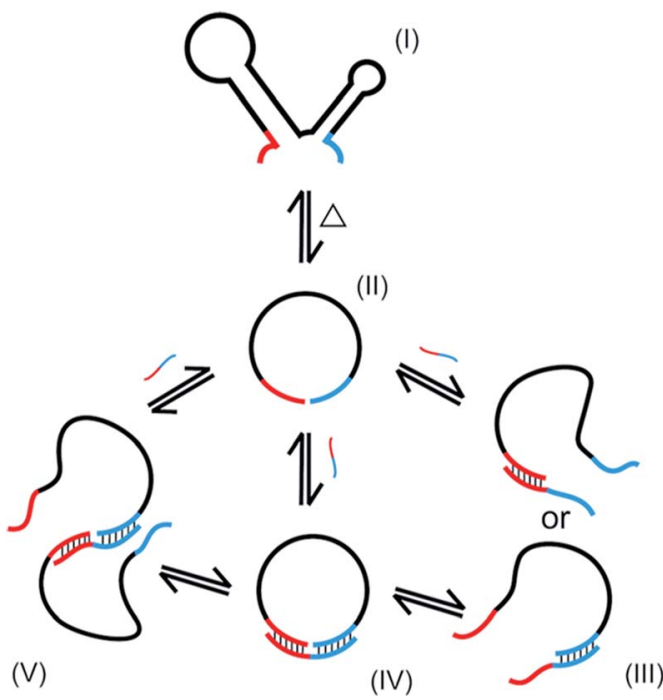

Scheme 2 Species formed in the mixtures for the cyclization of oligonucleotide by Taq DNA ligase. species are formed in equilibria. In III, either $3^{\prime}$-end of l-DNA or its $5^{\prime}$-end binds to the splint, whereas both ends simultaneously bind to the splint in IV. The composite IV is the major active species for the intramolecular cyclization. The binding of the splint to l-DNA could be promoted by the assistance of Taq DNA ligase. When two molecules of II are bound each other by one splint, the composite $\mathrm{V}$ is formed, which is responsible for the formation of polymeric byproducts. Note that the yield of DNA ring in the present enzymatic cyclization is primarily proportional to the concentration of the composite IV (with some contribution of III). On the other hand, the selectivity for the formation of DNA ring is governed by the ratio of the concentration of IV to that of $\mathrm{V}$.

The first requisite for successful cyclization is the formation of the composite IV at high temperatures. Thus, the GC content in the splint (and the number of G-C pairs in the composite IV) must be sufficiently high (Fig. 3). When the splint length is systematically increased, the yield first increases (the left-hand side of the bell-shaped curves in Fig. 2C). In the right-hand sides of the curves, however, the increase in the splint length destabilizes IV due to increased strain in the cyclic structures of the composite. The length of single-stranded portion in the composite, which mostly militates the strain in the cyclic structure, is gradually shortened and becomes ineffective (note that the double-stranded portions are too rigid for this purpose). As the result, the intramolecular cyclization becomes less efficient when the splint is too long. This argument fairly agrees with the results in Fig. 4 which shows critical importance of the size of DNA rings for the present enzymatic cyclization. As shown in Fig. 2D, the selectivity for the production of DNA ring is virtually constant irrespective of the splint length up to $31 \mathrm{nt}$, since $[\mathrm{IV}] /[\mathrm{V}]$ ratio is not much changed here. The secondary structure has been almost completely destroyed, so that the binding mode of splint to l-DNA in IV (for the intramolecular cyclization) is similar to that in $\mathrm{V}$ (for the intermolecular polymerization). With further increase of splint length, however, IV is destabilized by the increased strain of cyclic structure, as described above, decelerating the intramolecular cyclization. On the other hand, the stability of intermolecular composite $\mathrm{V}$ is never affected by this factor, and thus the $[\mathrm{IV}] /[\mathrm{V}]$ ratio (and thus the selectivity) is steeply decreased with increasing splint length.

Interestingly, the $T_{\mathrm{m}}$ of splint/l-DNA for the optimal length (25 nt) of splint was only $55.2{ }^{\circ} \mathrm{C}$ (date not shown), which is 
about $10{ }^{\circ} \mathrm{C}$ lower than the reaction temperature of $65{ }^{\circ} \mathrm{C}$. Similarly, for the ligation at $70{ }^{\circ} \mathrm{C}$, the optimal length of splint was $29 \mathrm{nt}$, and the $T_{\mathrm{m}}$ of splint/l-DNA $\left(60.8^{\circ} \mathrm{C}\right.$, date not shown) was also about $10{ }^{\circ} \mathrm{C}$ lower than the reaction temperature. Longer splints gave more polymeric byproducts, indicating that a $T_{\mathrm{m}}$ of about $10{ }^{\circ} \mathrm{C}$ lower than the reaction temperature is favorable for cyclization.

By reducing the concentration of Taq DNA ligase buffer, the selectivity for the formation of DNA rings was greatly promoted (Fig. 5). The formation of polymeric byproducts was almost completely suppressed in $0.1 \times$ Taq DNA ligase buffer, and the selectivity for the ring formation was close to $100 \%$. This result is consistent with the previous finding in the cyclization by $\mathrm{T} 4$ DNA ligase that concurrent polymerization was suppressed in highly diluted T4 DNA ligase buffer. ${ }^{26}$ The remarkable effect of T4 DNA ligase buffer concentration was ascribed to dominant contribution of nonprocessive ligation process in these buffers, in which the ligase dissociates from the DNA during the catalysis. ${ }^{3940}$ Compared with processive ligation in which all the catalysis is completed without dissociation of the enzyme, entropic advantage of the intramolecular ligation (cyclization) over the intermolecular polymerization is more significant. Whether a similar mechanism is in fact operative in the present cyclization or not cannot be concluded at present, since detailed kinetic information on Taq DNA ligase is not available.

By the present method, DNA rings of various of sizes and sequences can be prepared, which should be significant for further developments of nanoarchitectonics. The selectivity of these reactions is satisfactorily high. Unfortunately, however, Taq DNA ligase, which is currently available from commercial sources may be not completely stable at higher temperatures. Accordingly, the cyclization does not easily attain 100\% completion (in most cases, the conversion is $50-80 \%$, Fig. S5 $\dagger$ ). Further increase of the thermostability of this enzyme through mutation experiments and/or discovery of new thermostable DNA ligases should be one of the solutions, and promote the practical usefulness of the present methodology still more.

\section{Conclusion}

Even when oligonucleotides are folded to complicated secondary structures in solutions and otherwise hardly cyclized, DNA rings can be successfully prepared by using Taq DNA ligase at high temperatures. The use of Taq DNA ligase is absolutely necessary, since conventionally employed T4 DNA ligase overwhelmingly produces polymeric byproducts and the amount of ring products is only limited. To guarantee both yield and selectivity of DNA rings using Taq DNA ligase, G-C rich splints of sufficient length (e.g. 25-29 nt) must be used. Furthermore, diluted Taq DNA ligase buffer significantly suppresses the formation of polymeric byproducts. Accordingly, desired DNA rings can be easily obtained in sufficiently high purity, simply by (i) cyclizing the corresponding oligonucleotide by Taq DNA ligase at $70{ }^{\circ} \mathrm{C}$ in $0.1 \times \mathrm{Taq}$ DNA ligase buffer, and (ii) treating the reaction product with Exonuclease I to remove non-cyclic DNAs. No complicated purification procedures are necessary. Many single-stranded DNAs take secondary structures so that the scope of the DNA rings available (and of the relevant nanoarchitectonics) should be greatly extended by this finding. Furthermore, DNA rings involving complicated secondary structures can be easily obtained by the present method using Taq DNA ligase. They should show novel properties in chemical, physical, and biological functions, and are highly useful components for future nanoarchitectonics.

\section{Conflicts of interest}

None declared.

\section{Acknowledgements}

This work was supported by National Natural Science Foundation of China [31571937 to X. L.]; and the Fundamental Research Funds for the Central Universities [201713050 to R. A.]. Funding for open access charge: National Natural Science Foundation of China.

\section{References}

1 K. Wang, M. Q. He, F. H. Zhai, J. Wang, R. H. He and Y. L. Yu, Biosens. Bioelectron., 2018, 105, 159-165.

2 H. Xu, Y. Jiang, D. Liu, K. Liu, Y. Zhang, S. Yu, Z. Shen and Z. S. Wu, Anal. Chim. Acta, 2018, 1011, 86-93.

3 C. Teller and I. Willner, Curr. Opin. Biotechnol., 2010, 21, 376-391.

4 M. Komiyama, K. Yoshimoto, M. Sisido and K. Ariga, Bull. Chem. Soc. Jpn., 2017, 90, 967-1004.

5 C. Gaillard and F. Strauss, PLoS One, 2015, 10, e0119368.

6 L. Finn, A. Damian and F. Michael, J. Am. Chem. Soc., 2012, 134, 11884-11887.

7 C. H. Lu, A. Cecconello, X. J. Qi, N. Wu, S. S. Jester, M. Famulok, M. Matthies, T. L. Schmidt and I. Willner, Nano Lett., 2015, 15, 7133-7137.

8 X. J. Qi, C. H. Lu, A. Cecconello, H. H. Yang and I. Willner, Chem. Commun., 2014, 50, 4717-4720.

9 C. H. Lu, A. Cecconello and I. Willner, J. Am. Chem. Soc., 2016, 138, 5172-5185.

10 L. Hu, C. H. Lu and I. Willner, Nano Lett., 2015, 15, 20992103.

11 X. Liang, H. Kuhn and M. D. Frank-Kamenetskii, Biophys. J., 2006, 90, 2877-2889.

12 E. T. Kool, Annu. Rev. Biophys. Biomol. Struct., 1996, 25, 1-28. 13 X. Wang, C. Li, X. Gao, J. Wang and X. Liang, Mol. Ther.Nucleic Acids, 2015, 4, e215.

14 Y. Liu, A. Kuzuya, R. Sha, J. Guillaume, R. Wang, J. W. Canary and N. C. Seeman, J. Am. Chem. Soc., 2008, 130, 10882-10883.

15 H. Kuhn, V. V. Demidov and M. D. Frank-Kamenetskii, Nucleic Acids Res., 2002, 30, 574-580.

16 J. Marciniak, A. Kummel, S. Esener, M. Heller and B. Messmer, BioTechniques, 2008, 45, 275-280.

17 D. Y. Zhang, M. Brandwein, T. Hsuih and H. B. Li, Mol. Diagn., 2001, 6, 141-150.

18 R. Deng, L. Tang, Q. Tian, Y. Wang, L. Lin and J. Li, Angew. Chem., Int. Ed. Engl., 2014, 53, 2389-2393. 
19 T. Murakami, J. Sumaoka and M. Komiyama, Nucleic Acids Res., 2009, 37, e19.

20 A. E. Tomkinson, S. Vijayakumar, J. M. Pascal and T. Ellenberger, Chem. Rev., 2006, 106, 687-699.

21 A. J. Doherty and T. R. Dafforn, J. Mol. Biol., 1999, 296, 43-56. 22 R. Rossi, A. Montecucco, G. Ciarrocchi and G. Biamonti, Nucleic Acids Res., 1997, 25, 2106-2113.

23 J. D. Kahn and D. M. Crothers, Proc. Natl. Acad. Sci. U. S. A., 1992, 89, 6343-6347.

24 Z. S. Wu, Z. Shen, K. Tram and Y. Li, Nat. Commun., 2014, 5, 4279.

25 M. Liu, Q. Zhang, Z. Li, J. Gu, J. D. Brennan and Y. Li, Nat. Commun., 2016, 7, 12074.

26 R. An, Q. Li, Y. Fan, J. Li, X. Pan, M. Komiyama and X. Liang, Nucleic Acids Res., 2017, 45, e139.

27 J. SantaLucia Jr and D. Hicks, Annu. Rev. Biophys. Biomol. Struct., 2004, 33, 415-440.

28 D. Bikard, C. Loot, Z. Baharoglu and D. Mazel, Microbiol. Mol. Biol. Rev., 2010, 74, 570-588.

29 L. Hu, C. H. Lu and I. Willner, Nano Lett., 2015, 15, 20992103.
30 J. Tong, F. Barany and W. Cao, Nucleic Acids Res., 2000, 28, 1447-1454.

31 J. Luo, D. E. Bergstrom and F. Barany, Nucleic Acids Res., 1996, 24, 3071.

32 J. Tong, W. Cao and F. Barany, Nucleic Acids Res., 1999, 27, 788-794.

33 M. Zuker, Nucleic Acids Res., 2003, 31, 3406-3415.

34 J. Wang, P. Dong, W. Wu, X. Pan and X. Liang, J. Biomol. Struct. Dyn., 2018, 36, 1-13.

35 J. Wang, X. Pan and X. Liang, J. Anal. Methods Chem., 2016, 2016, 1-8.

36 J. Luo, D. E. Bergstrom and F. Barany, Nucleic Acids Res., 1996, 24, 3071-3078.

37 G. J. S. Lohman, R. J. Bauer, N. M. Nichols, L. Mazzola, J. Bybee, D. Rivizzigno, E. Cantin and T. J. Evans, Nucleic Acids Res., 2016, 44, e14.

38 J. Stewart, P. Kozlowski, M. Sowden, E. Messing and C. Smith, Nucleic Acids Res., 1998, 26, 961-966.

39 A. V. Cherepanov and V. S. De, J. Biol. Chem., 2002, 277, 1695-1704.

40 A. V. Cherepanov and V. S. De, Eur. J. Biochem., 2003, 270, 4315-4325. 